(C) D. Laukhin 1 , O. Beketov ${ }^{2}$, Y. Slupska ${ }^{2}$, E. Babenko ${ }^{2}$, N. Rott ${ }^{1}$, V. Dytiuk ${ }^{1}$ ${ }^{1}$ Dnipro University of Technology, Dnipro, Ukraine

${ }^{2}$ State Higher Educational Establishment «Prydniprovska State Academy of Civil Engineering and Architecture», Dnipro, Ukraine

\title{
METALLOGRAPHIC ANALYSIS OF POTENTIAL AREAS OF DESTRUCTION INITIATION OF THE ZONE OF THERMAL IMPACT OF LOW-CARBON STEELS AFTER LASER WELDING
}

\author{
(С) Д.В. Лаухін ${ }^{1}$, О.В. Бекетов ${ }^{2}$, Ю.С. Слупська ${ }^{2}$, С.О. Бабенко ${ }^{2}$, Н.О. Ротт ${ }^{1}$, В.Е. Дитюк ${ }^{1}$ \\ ${ }^{1}$ Національний технічний університет «Дніпровська політехніка», Дніпро, Україна \\ 2 Державний вищий навчальний заклад «Придніпровська державна академія будів- \\ ництва та архітектури», Дніпро, Україна
}

\section{МЕТАЛОГРАФІЧНИЙ АНАЛІЗ ПОТЕНЦЙННИ ДІЛЯНОК ЗАРОДЖЕННЯ РУЙНУВАННЯ ЗОНИ ТЕРМІЧНОГО ВЛИВУ НИЗЬКОВУГЛИЦЕВИХ СТАЛЕЙ ПІСЛЯ ЛАЗЕРНОГО ЗВАРЮВАННЯ}

Purpose. To find out dangerous areas of the zone of thermal impact on the basis of the research of welding joint structure formation after laser welding of low-carbon structural steels $09 \mathrm{Mn} 2 \mathrm{Si}$, $10 \mathrm{CrNiCu}, 10 \mathrm{Mn} 2 \mathrm{VNb}$.

The methods. In research are used methods of studying the structure and fine structure of materials, namely raster electron microscopy using a scanning electron microscope PEM-106И.

Findings. The work investigates the detection of dangerous areas of the zones of thermal impact on the basis of the research of welding joint structure formation after laser welding of low-carbon steels $09 \mathrm{Mn} 2 \mathrm{Si}, 10 \mathrm{CrNiCu}, 10 \mathrm{Mn} 2 \mathrm{VNb}$. The complex of studies carried out showed that the welded joint is structurally divided into several zones. At the same time, metallographic analysis showed that in the zones of the welded joint there is a conglomerate of structures, which contains components characteristic both for metal in the cast state and for metal after accelerated cooling.

The originality. The established dependences show that the significant differences in structural state were found out on the boundary between the joint and the zone of thermal impact (the boundary between areas 1 and 2). It means that in this area a significant increase in the level of microstrength will be observed, comparing to the other joint areas. Taking into account the width of this zone, it should be stressed that the concentration of mechanical strength will occur in a relatively narrow zone of the welding joint. As a result, this zone will be a potential place for the accumulation of defects and will significantly influence the mechanical properties of the whole joint.

Practical implimintation. Improving the results obtained and conducting new research on this topic will allow the development of improved modes of welding of high-strength steels, taking into account the structural state and operating conditions of rolled metal.

Key words: Laser welding, low-carbon steel, welding joint structure, structural components, welding joint zones

Introduction. While welding by traditional methods, mechanical properties of finished articles can decrease significantly. This is because at high-speed heating and quick cooling in the zone of weld seam a heterogeneous gradient structure is formed. This 
structure is characterized by an increased level of residual stress. One way to solve this problem is to use welding works of highly concentrated energy flows in the technological scheme, e.g. to use laser emission $[1,2]$.

Main part. Nowadays, laser welding has become one of the main processes while manufacturing structural steel products [1]. The spread of this type of welding can be explained, first of all, by the low level of residual stress in combination with relatively traditional methods of welding. The decrease in the level of microstress is reached by the application of concentrated emission while laser welding, which enables to carry out the process in a narrow zone. [2].

Publications review (e.g. [1-4]) shows that the structure of welding joints can be represented as a scheme given in fig. 1. According to the level of impact of high temperatures on the metal in the zone of thermal impact, it is possible to distinguish the following areas: the area of incomplete meltdown, the area of overheating, the area of normalization, the area of incomplete crystallization, and the area of recrystallization. Let`s examine some of these areas in details.

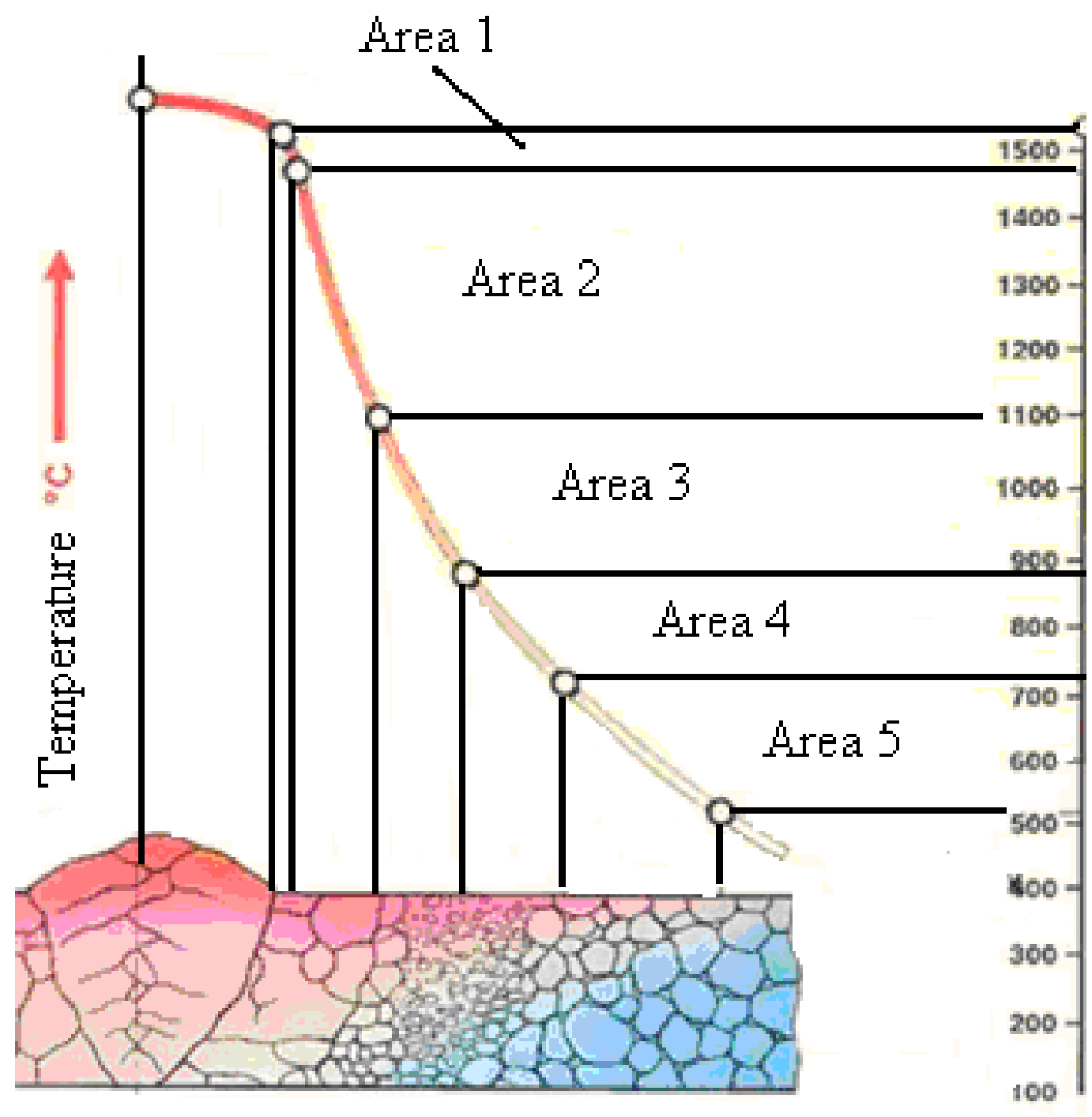

Fig. 1. Schematic representation of welding joint of low-carbon and microalloyed steels [4] 
Area 1 is transitional from weld material to base metal. It is the area of base metal heated to the melting temperature. While further cooling, metal crystallization occurs in this zone. From the structural point of view, this area is characterized by the presence of both foundry and recrystallized structural components [2-4].

Area 2 - the area of highly heated metal with recrystallized structure of austenite [2-4].

Area 3 the area of metal heated to the temperature of phase recrystallization. While further cooling, $\gamma-\alpha$ phase transformations with anisomerous structure occur [2-4].

Area 4 is also characterized by anisomerous features. Neat the big ferrite grains, there are small ferrite grains formed in the process of recrystallization [2-4].

Area 5 base metal heated to the temperature Ac1 [2-4].

Herewith, the publications review [3-6] shows that the separation boundaries between the areas of the joint, characterized by different structural state, are potential places of destruction initiation. As a result, it is important to provide metallographic quality of the indicated zones. Thus, the purpose of this work is to find out dangerous areas of the zone of thermal impact on the basis of the research of welding joint structure formation after laser welding of low-carbon structural steels $09 \mathrm{Mn} 2 \mathrm{Si}$, $10 \mathrm{CrNiCu}, 10 \mathrm{Mn} 2 \mathrm{VNb}$.

As a research material, low-carbon microalloyed steels $09 \mathrm{Mn} 2 \mathrm{Si}, 10 \mathrm{CrNiCu}$, $10 \mathrm{Mn} 2 \mathrm{VNb}$ were selected. The chemical composition of the studied steel grades is represented in table 1.

Table 1

Chemical composition of steels $09 \mathrm{Mn} 2 \mathrm{Si}, 10 \mathrm{CrNiCu}, 10 \mathrm{Mn} 2 \mathrm{VNb}$

\begin{tabular}{|c|c|c|c|c|c|c|c|c|c|c|c|}
\hline Steel & $\mathrm{C}$ & $\mathrm{Si}$ & $\mathrm{Mn}$ & $\mathrm{Ni}$ & $\mathrm{S}$ & $\mathrm{P}$ & $\mathrm{Cr}$ & $\mathrm{V}$ & $\mathrm{N}$ & $\mathrm{Cu}$ & $\mathrm{Fe}$ \\
\hline 09Mn2Si & to 0.12 & \begin{tabular}{|c}
$0.5-$ \\
0.8 \\
\end{tabular} & $\begin{array}{l}1.3- \\
1.7 \\
\end{array}$ & to 0.3 & \begin{tabular}{|c|} 
to \\
0.035 \\
\end{tabular} & \begin{tabular}{|c|} 
to \\
0.03 \\
\end{tabular} & to 0.3 & $\begin{array}{c}\text { to } \\
0.12\end{array}$ & $\begin{array}{c}\text { to } \\
0.008 \\
\end{array}$ & $\begin{array}{c}\text { to } \\
0.3 \\
\end{array}$ & residual \\
\hline $10 \mathrm{CrNiCu}$ & to 0.12 & $\begin{array}{c}0.8- \\
1.1 \\
\end{array}$ & $\begin{array}{c}0.5- \\
0.8 \\
\end{array}$ & $\begin{array}{c}0.5- \\
0.8 \\
\end{array}$ & \begin{tabular}{|c|} 
to \\
0.04 \\
\end{tabular} & \begin{tabular}{|c|} 
to \\
0.035 \\
\end{tabular} & $\begin{array}{c}0.6- \\
0.9 \\
\end{array}$ & - & $\begin{array}{c}\text { to } \\
0.008\end{array}$ & $\begin{array}{c}0.4- \\
0.6 \\
\end{array}$ & - \\
\hline $10 \mathrm{Mn} 2 \mathrm{VNb}$ & $\begin{array}{c}0.08- \\
0.13\end{array}$ & $\begin{array}{l}0.15- \\
0.35\end{array}$ & $\begin{array}{c}1.6- \\
1.8 \\
\end{array}$ & & \begin{tabular}{|c} 
to \\
0.035 \\
\end{tabular} & \begin{tabular}{|c|} 
to \\
0.03 \\
\end{tabular} & to 0.3 & $\begin{array}{c}0.05- \\
0.12\end{array}$ & - & - & - \\
\hline
\end{tabular}

These steels underwent thermomechanical processing under the technological scheme of uninterrupted controlled rolling [7], the scheme of which is represented in fig. 2. 


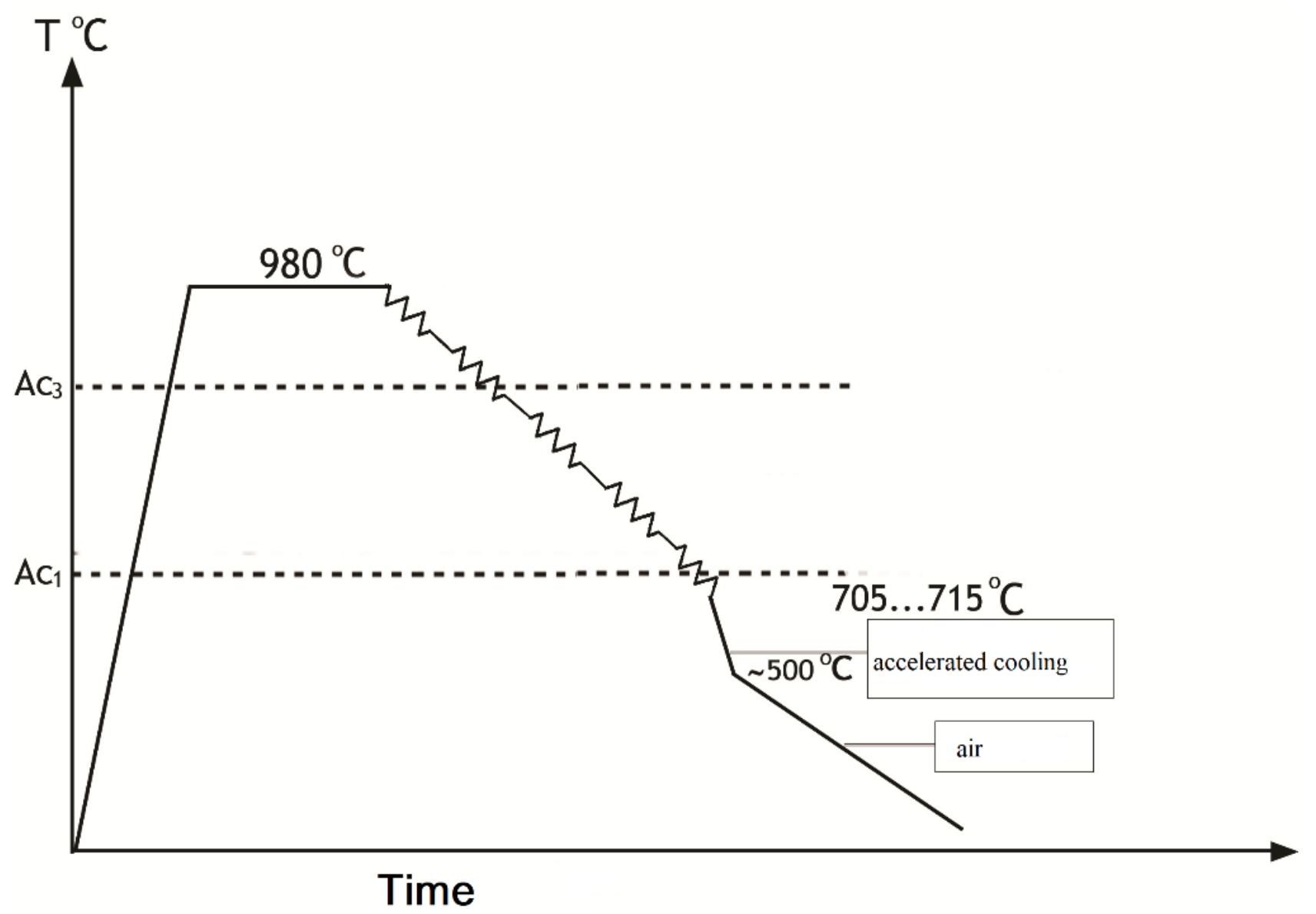

Fig. 2. Scheme of the thermomechanical processing regime [7]

The microstructure of the studied steels is given in fig. 3 .

The analysis of the data in fig. 3 shows that for all the studied steel grades, there is a fine-grained ferrite-perlite conglomerate in the structure. At the same time, a perlite component has a thinner construction (comparing to the usual, e.g. [8]). Such perlite is called quasi-eutectoid [9].

The formation of quasi-eutectoid is conditioned by diffusion redistribution that leads to the formation of perlite colonies at carbon concentration less than by $0,8 \%$.

Experimental welding was performed at the equipment of E.O. Paton Institute of electric welding NAS Ukraine. Laser was used to weld docking joints of the plates $290 \times 140 \times 18 \mathrm{~mm}$; Nd:YAG-laser model DY 044 («Rofin Sinar», Germany) of the capacity to $4,4 \mathrm{~kW}$ with focal distance $\mathrm{F}=300 \mathrm{~mm}$. The emission from the laser to the object was transmitted through optical fiber of the diameter $600 \mu \mathrm{m}$. While welding, a welding head with a security system moved. The root part of the welding joint is in the atmosphere (Ar+ CO2 ). The puddle and its tail piece were protected with the help of the welding head nozzle. The speed of welding was $1.5 \mathrm{~m} / \mathrm{min}$. 


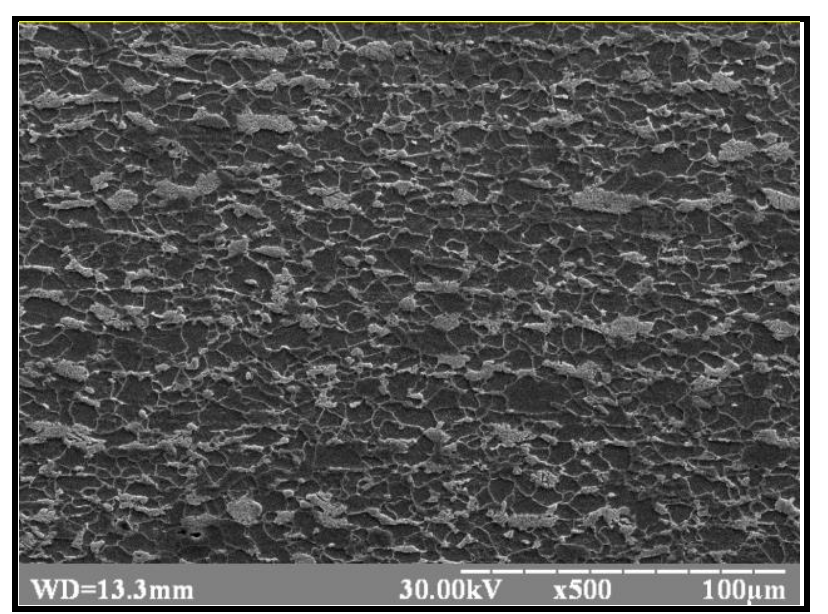

a

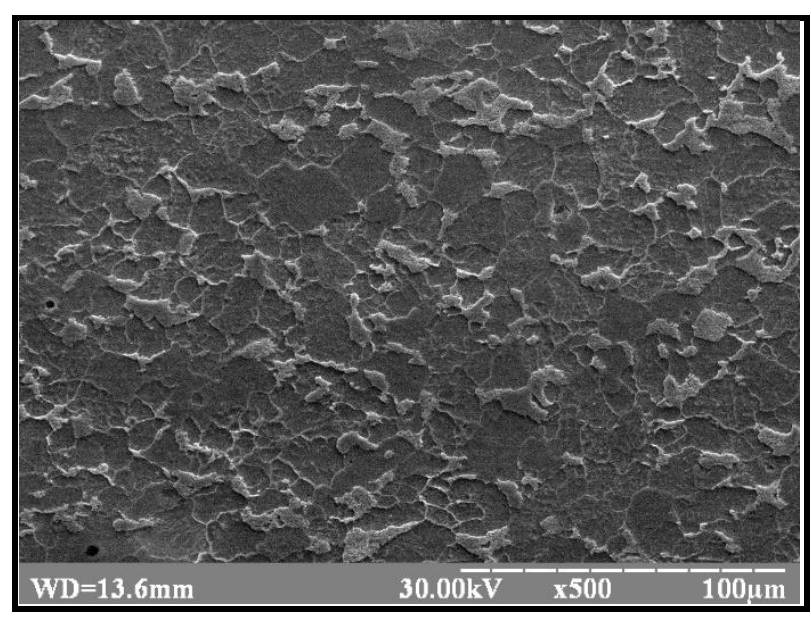

C

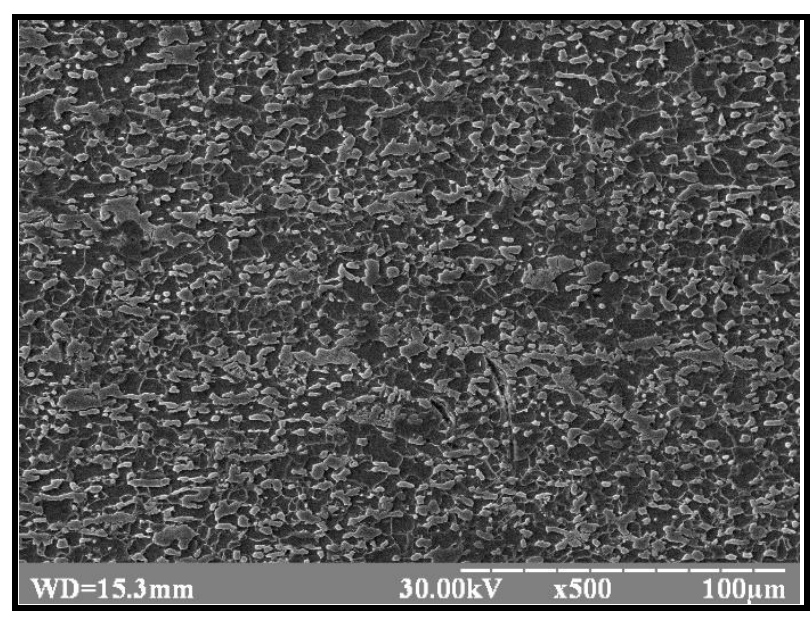

e

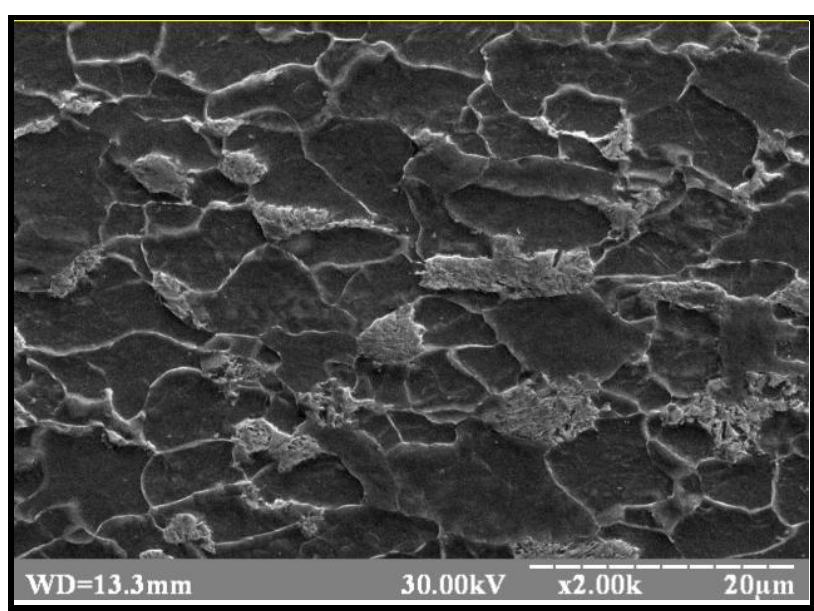

b

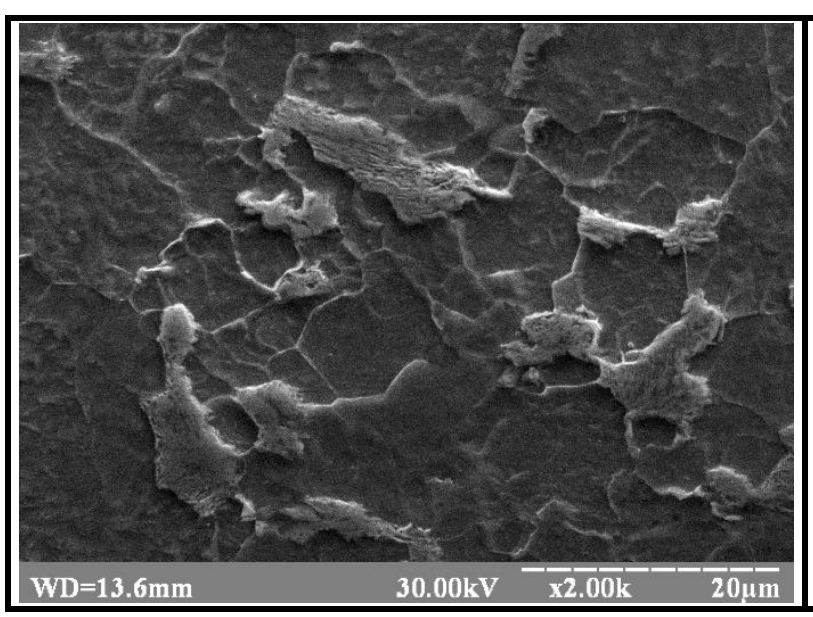

d

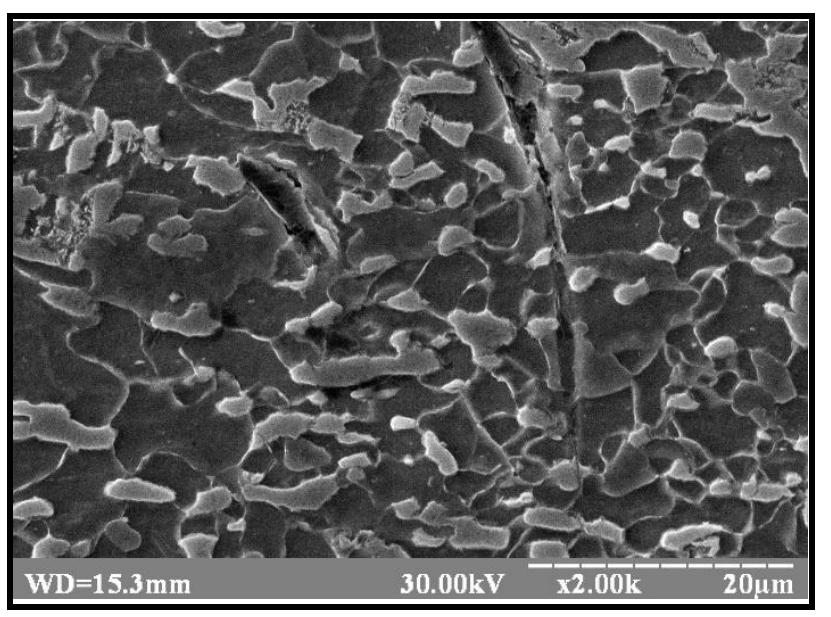

f

Fig. 3. Steel microstructure after experimental thermomechanical processing: a, b-09Mn2Si; c, d-10CrNiCu; e, f - 10Mn2 VNb

Results. The results of the research of the welding joint microstructure and after laser welding are represented in fig. 4, 5 .

The analysis of the data obtained shows that in area 1 crystallization of molten metal occurs. In addition, the crystallization process occurs with stops caused by the emission of latent heat of melting at the front of crystallization, and thus, by the 
decrease in the level of cooling. In some time, as a result of heat emission into the base metal and the environment, at the front of crystallization the necessary level of overcooling is established, the process of crystallization starts, and the front moves to a certain gradient of distance temperatures. This mechanism leads to the formation of the cast metal structure in a welding joint. The structure is partially inherited on the area of incomplete melting (fig. $4 \mathrm{a}, \mathrm{b}, \mathrm{c}$ ).

Area 2 is formed due to the effect of thermal load. After the process of crystallization, the metal of the zone has the structure of austenite. When reducing the temperatures to the phase transformation temperature, secondary recrystallization starts. As a result, ferrite grains are formed, while austenite is enriched by carbon, and eutectoid transformation occurs. Thus, the metal of the area has a structure with small ferrite grains and perlite colonies (fig. 4 b, c, d). In addition, for steel $10 \mathrm{CrNiCu}$ recrystallized ferrite grains can be observed (fig. $4 \mathrm{c}$ ). For steel $10 \mathrm{Mn} 2 \mathrm{VNb}$ the appearance of Widmanstätten type structures is observed (fig. $4 \mathrm{~d}$ ).

Area 3 is characterized by the presence of recrystallized ferrite grains and perlite colonies in the structure (fig. $5 \mathrm{a}, \mathrm{b}, \mathrm{e}$ ). For steel 09Mn2Si and 10Mn2 VNb in the area structure the appearance of Widmanstätten type structure (fig. $5 \mathrm{a}$ and $5 \mathrm{e}$, correspondingly).

The formation of this structural state is conditioned by the high speed of cooling and further normalization of the structure. The process of normalization occurs due to the additional heating at heat response from the welding joint, and as a result, the decrease in mechanical strength concentration and redistribution of crystal structure defects occur.

The structural state of area 4 is formed due to the heating to the temperatures of inter-critical interval. Such heating will lead to the formation of austenite with ferrite as well as to the increase in ferrite grains with which there is no recrystallization (fig. $5 \mathrm{~b}, \mathrm{c}, \mathrm{f}$ ). After cooling, at this area ferrite grains are present which did not undergo recrystallization and small ferrite grains as well, and perlite colonies formed from austenite at phase recrystallization. At the same time, for steel $09 \mathrm{Mn} 2 \mathrm{Si}$ and $10 \mathrm{Mn} 2 \mathrm{VNb}$ Widmanstätten type structures are present, however, their percentage is less than at area 3 (on average by $10 \%$ ).

A compatible data analysis (fig. 4,5) shows that there are no significant differences in the structural state between area 3 and area 4 . On the other hand, the structural state of the boundary between areas 1 and 2 is characterized by the presence of components that are different at their morphology (pre-eutectoid ferrite, perlite, Widmanstätten ferrite). It means that the level of microstrength on the boundary between these areas will be much larger comparing to other areas of the welding joint. Thus, from the energetic point of view, this area will be characterized by the increase in the level of free energy. As a result, the accumulation of defects will occur exactly on the boundary between areas 1 and 2 . 


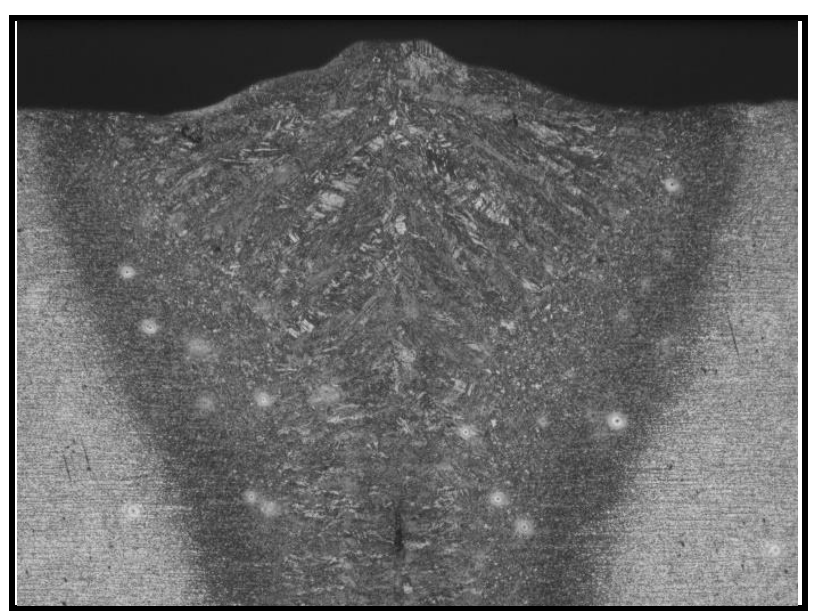

a

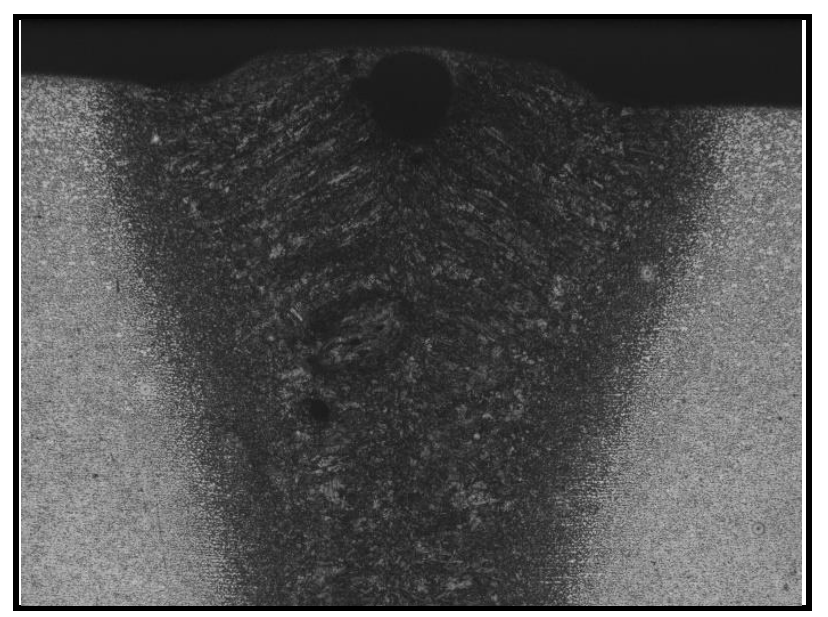

C

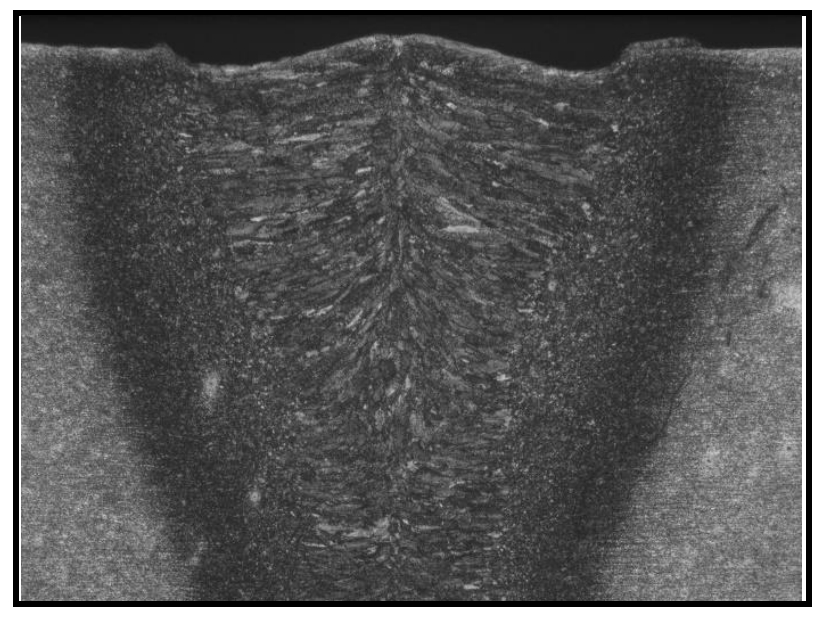

e

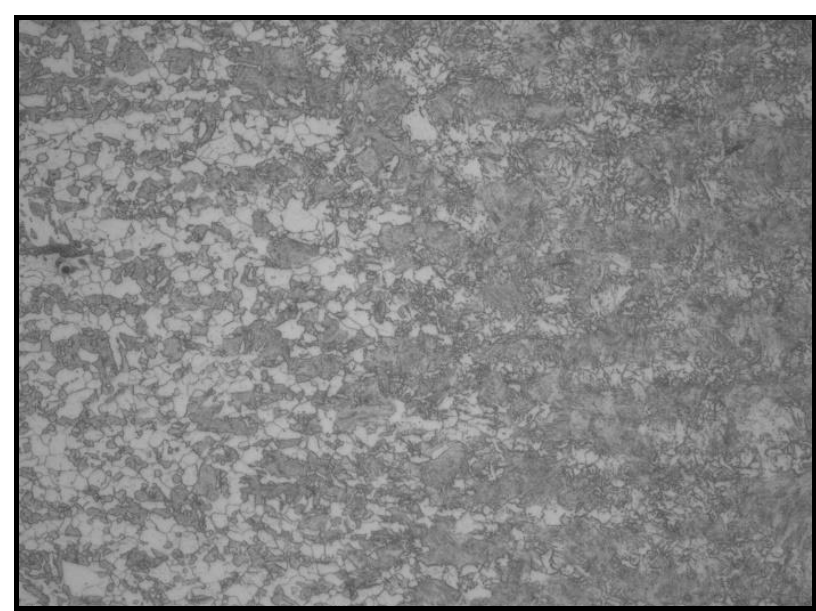

b

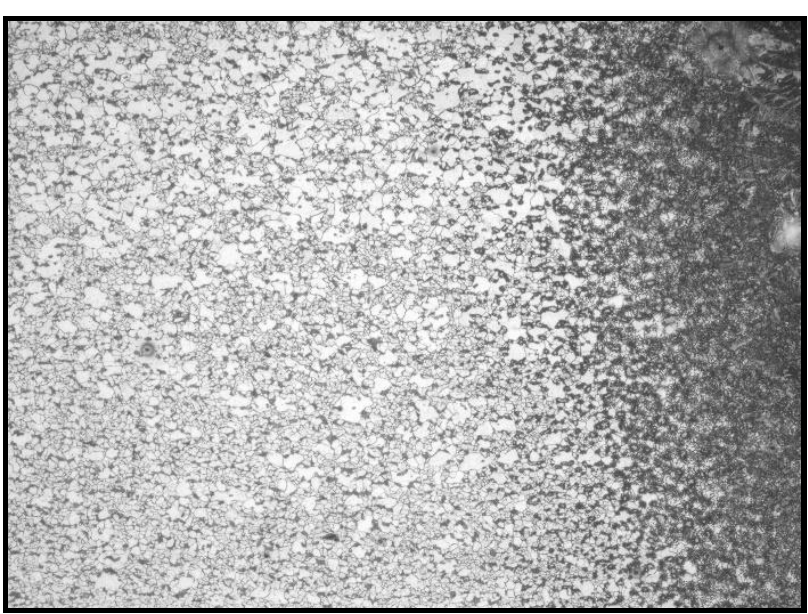

$\mathrm{d}$

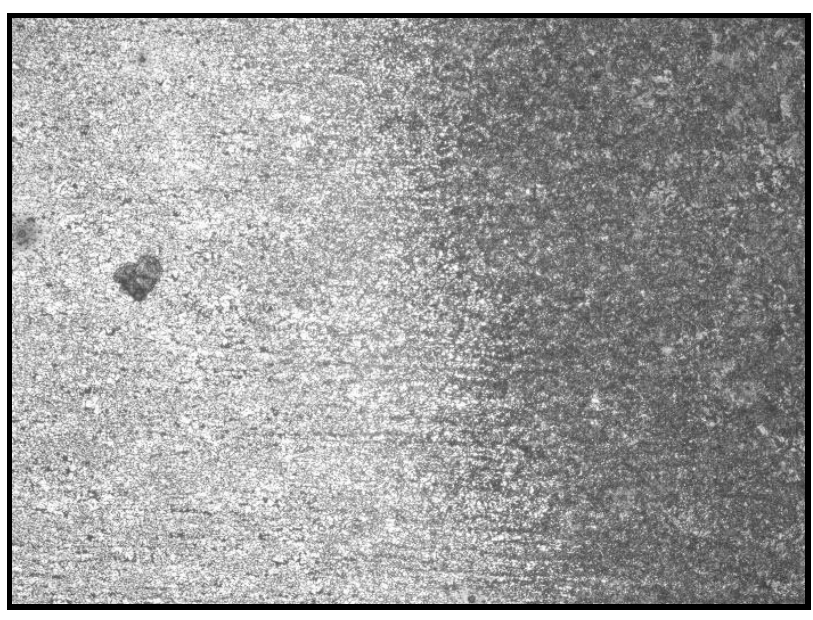

f

Fig. 4. Microstructure of welding joint after laser welding: $a, b-$ steel $-09 \mathrm{Mn} 2 \mathrm{Si}$; c, d-10CrNiCu; e, f - 10Mn2VNb; a, c, e - area 1; b, d, f - area 2. 


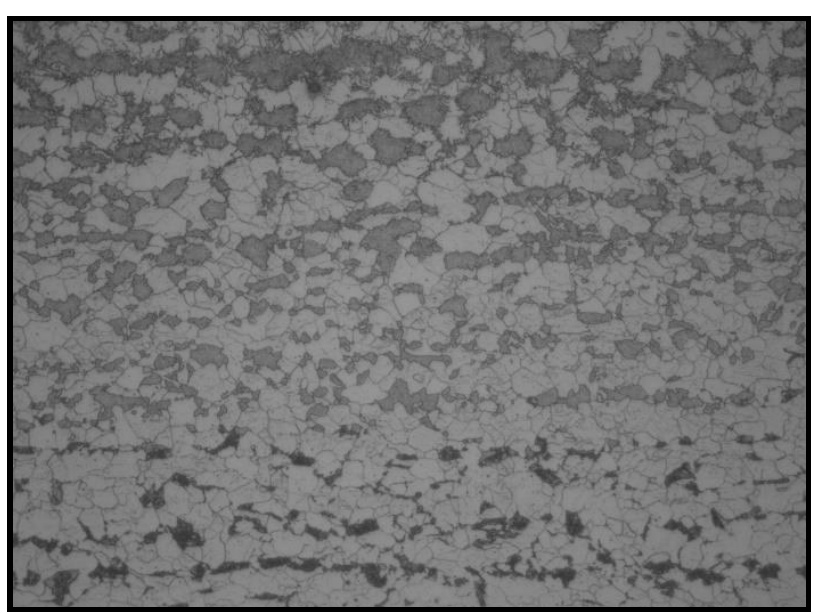

a

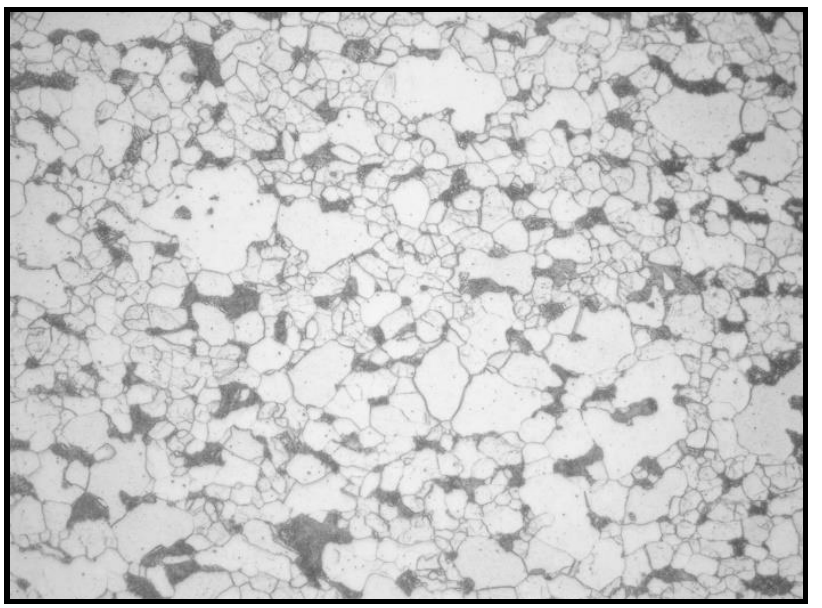

$\mathrm{c}$

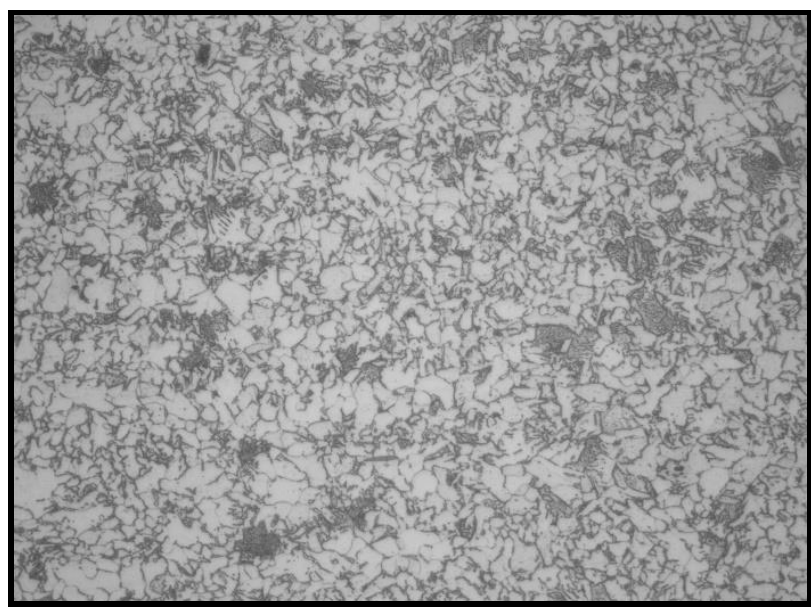

e

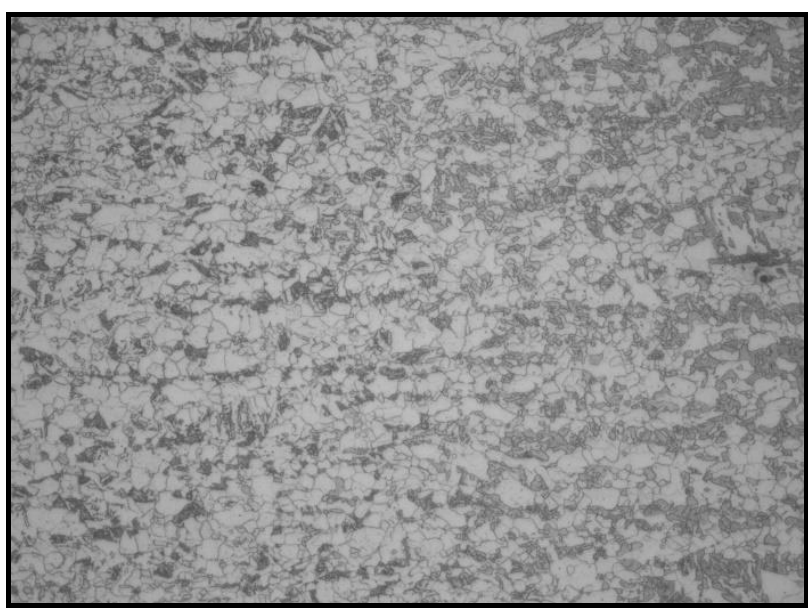

b

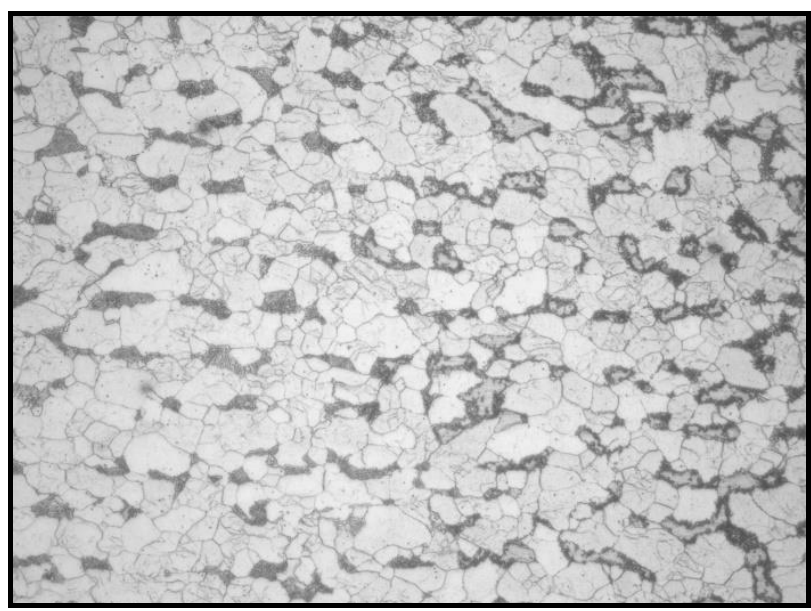

d

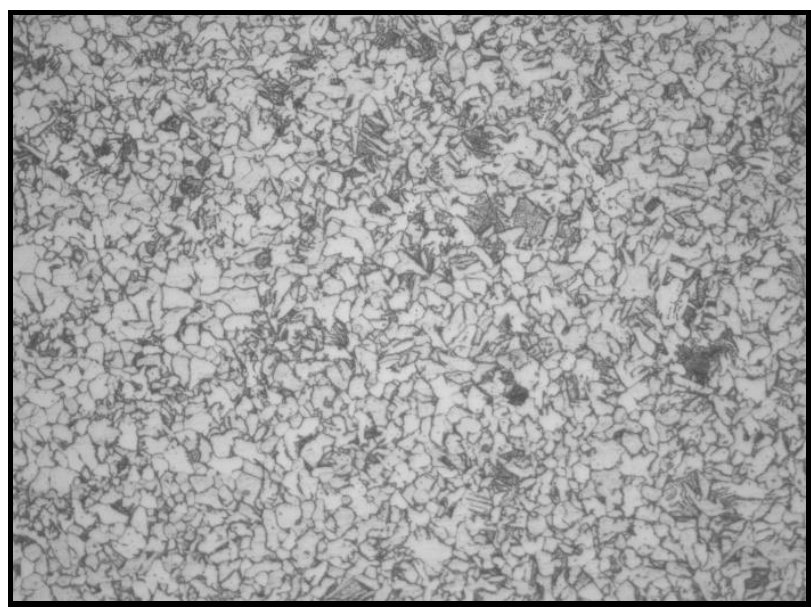

f

Fig. 5. Microstructure of welding joint after laser welding: $a, b-$ steel 09Mn2Si; c, d-steel 10CrNiCu; e, f - steel 10Mn2VNb; a, c, e - area 3; b, d, f - area 4.

With the aim of quantitative analysis of the data obtained, experimental measurement of geometrical dimensions of the boundaries between the areas was carried out. The data are generalized and given in table 2. 
Table 2

Geometrical dimensions of the boundaries between the areas of the welding joint

\begin{tabular}{|c|c|c|}
\hline Steel grade & $\begin{array}{c}\text { Boundary between areas } \\
1 \mathrm{Ta} 2, \mathrm{~mm}\end{array}$ & $\begin{array}{c}\text { Boundary between areas } \\
3 \mathrm{Ta} 4, \mathrm{~mm}\end{array}$ \\
\hline $09 \mathrm{Mn} 2 \mathrm{Si}$ & 0.8 & 3.2 \\
\hline $10 \mathrm{CrNiCu}$ & 1.4 & 2.6 \\
\hline $10 \mathrm{Mn} 2 \mathrm{VNb}$ & 0.6 & 2.4 \\
\hline
\end{tabular}

A complex and qualitative analysis of the data shows that the size of the boundaries between areas 1 and 2 is 2-3 times as small as the width of the boundary between areas 3 and 4 . It means that the concentration of mechanical strength occurs in a relatively narrow zone of the welding joint. It is the zone that is the most dangerous as for the accumulation of defects and potential destruction of welding joint.

Conclusions. 1. The work investigated the detection of dangerous areas of the zones of thermal impact on the basis of the research of welding joint structure formation after laser welding of low-carbon steels $09 \mathrm{Mn} 2 \mathrm{Si}, 10 \mathrm{CrNiCu}, 10 \mathrm{Mn} 2 \mathrm{VNb}$.

2. The complex of the research that was carried out showed that welding joint can structurally be divided into several zones, each of which has its own structural state. Herewith, the quality of welding joint is mainly influenced by the boundaries between structurally different areas of welding joint.

3. The metallographic analysis showed that in the welding joint there is a structure conglomerate that has components which are characteristics both of cast metal and recrystallized metal and quickly cooled metal (Widmanstätten ferrite).

4. The complex and qualitative analysis of the research showed that the significant differences in structural state were found out on the boundary between the joint and the zone of thermal impact (the boundary between areas 1 and 2). It means that in this area a significant increase in the level of microstrength will be observed, comparing to the other joint areas. Taking into account the width of this zone, it should be stressed that the concentration of mechanical strength will occur in a relatively narrow zone of the welding joint. As a result, this zone will be a potential place for the accumulation of defects and will significantly influence the mechanical properties of the whole joint.

\section{References}

1. Колубаев, А. В., Сизова, О. В., Колубаев, Е. А., Заикина, А. А., Воронцов, А. В., Денисова, Ю. А., \& Рубцов, В. Е. (2018). Особенности структуры сварного шва при лазерной сварке конструкционной стали 09Г2С. Обработка металлов: технология, оборудование, инструменты, 20(3), 123-133. http://doi.org/10.17212/1994-6309-2018-20.3-123-133

2. Деревягина, Л. С., Гордиенко, А. И., Оришич, А. М., Маликов, А. Г., \& Сурикова, Н. С. (2019). Особенности формирования зон термического влияния лазерного сварного соединения низкоуглеродистой феррито-перлитной стали. Перспективные Материалы с Иерархической Структурой Для Новых Технологий и Надежных Конструкиий: Тезы Докл. Всерос. Науч.-Практ. Конф., г. Томск, 1-3 Окт. 2019 г. Россия- Томск, 611-612. https://doi.org/10.17223/9785946218412/407 
3. Лазарева, А. И., Копцева, Н. В., Горленко, Д. А., Ефимова, Ю. Ю., Никитенко, О. А., \& Голубчик, Э. М. (2016). Исследование влияния термической обработки на качество сварных соединений в условиях агрегатов второй очереди листопрокатного цеха № 11 ОАО" Магнитогорский металлургический комбинат". Вестник Пермского национального исследовательского политехнического университета. Машиностроение, материаловедение, 18(4), 60-73. https://doi.org/10.15593/2224-9877/2016.4.05

4. Структура зоны термического влияния при сварке. (n.d.). Онлайн Справочник о Сварке. http://osvarke.net/soedineniya/zona-termicheskogo-vliyaniya/

5. Глизманенко, Д.Л. (1984). Сварка и резка металлов: учеб. пособ. Изд. 5-е переработанное. Москва: Металлургия.

6. Волченко, В.Н. (1991). Сварка и свариваемые материалы. Справочник. m.1.

7. Laukhin, D., Beketov, O., Rott, N., \& Schudro, A. (2019). The Elaboration of Modernized Technology of Controlled Rolling Directed at the Formation of High Strengthening and Viscous Qualities in HSLA Steel. Solid State Phenomena, 291, 13-19. https://doi.org/10.4028/www.scientific.net/SSP.291.13

8. Suhomlin, G. D., Laukhin, D. V., Beketov, A. V., \& Mashkovskaya, A. V. (2015). Дослідження поверхневої енергії міжфазних границь під час дифузійного $\gamma \rightarrow \alpha$ перетворення. Physical Metallurgy and Heat Treatment of Metals, 2(69), 24-29.

9. Сухомлин, Г.Д. (1976). Исследование морфологии и кристаллогеометрии при ускоренном прерванном охлаждении в процессе термомеханической обработке труб. Дис. на присвоение уч. степени к.т.н. Днепропетровск

\section{АННОТАЦИЯ}

Цель. Выявление опасных участков зоны термического влияния на основании исследования формирования структуры сварного соединения после лазерной сварки низкоуглеродистых конструкционных сталей 09Г2С, 10ХСНД, 10Г2ФБ.

Методика. В работе использованы современные методы исследования структуры и тонкой структуры материалов, а именно растровую электронную микроскопию с применением сканирующего электронного микроскопа РЭС-106И.

Результаты. Исследовано выявление опасных участков зоны термического влияния на основании исследования формирования структуры сварного соединения после лазерной сварки низкоуглеродистых сталей 09Г2С, $10 Х \mathrm{XСД,} \mathrm{10Г2ФБ.} \mathrm{Проведенный} \mathrm{комплекс} \mathrm{исследований}$ показал, что сварное соединение структурно разделить на несколько зон. При этом, металлографический анализ показал, что в зонах сварного соединения присутствуют конгломерат структур, который содержит составляющие характерные как для металла в литом состоянии так и для металла после ускоренного охлаждения.

Научная новизна. Установлены зависимости показывают, что значительные различия в структурном состоянии обнаружено на границе между швом и зоной термического воздействия (граница между участками 1 и 2). Это означает, что в данной области будет наблюдаться значительное увеличение степени микронапряжений, по сравнению с другими участками шва. Учитывая ширину данной зоны, возможно заметить, что концентрация механических напряжений будет происходит в сравнительно узкой зоне сварного соединения. Как следствие, эта зона будет потенциально местом для накопления дефектов и осуществлять значительное влияние на механические свойства всего соединения.

Практическая значимость. Совершенствование полученных результатов и проведения новых исследований по данной тематике позволит разработать усовершенствованные режимы 
сварки высокопрочных сталей с учетом структурного состояния и условий эксплуатации металлопроката.

Ключевые слова: лазерная сварка, низкоуглеродистая сталь, структура сварного соединения, структурные составляюшие, зоны сварного соединения.

\begin{abstract}
АНОТАЦІЯ
Мета. Виявлення небезпечних ділянок зони термічного впливу на підставі дослідження формування структури зварного з'єднання після лазерного зварювання низьковуглецевих конструкційних сталей 09Г2С, 10ХСНД, 10Г2ФБ.
\end{abstract}

Методика. У роботі використано сучасні методи дослідження структури та тонкої структури матеріалів, а саме растрову електронну мікроскопію з застосуванням скануючого електронного мікроскопу РЕМ-106И.

Результати. Досліджено виявлення небезпечних ділянок зони термічного впливу на підставі дослідження формування структури зварного з'єднання після лазерного зварювання низьковуглецевих сталей 09Г2С, 10ХСНД, 10Г2ФБ. Проведений комплекс досліджень показав, що зварене з'єднання структурно розділити на кілька зон. При цьому, металографічний аналіз показав, що в зонах зварного з'єднання присутні конгломерат структур, який містить складові характерні як для металу в литому стані так і для металу після прискореного охолодження.

Наукова новизна. Встановлені залежності показують, що значні відмінності в структурному стані виявлено на границі між швом та зоною термічного впливу (границя між ділянками 1 та 2). Це означає, що в даній області буде спостерігатися значне збільшення ступеню мікронапружень, порівняно з іншими ділянками шва. Враховуючи ширину даної зони, можливо зауважити, що концентрація механічних напружень буде відбувається в порівняно вузькій зоні зварного з'єднання. Як наслідок, ця зона буде потенціальнім місцем для накопичення дефектів і здійснювати значний вплив на механічні властивості всього з'єднання.

Практична значимість. Вдосконалення отриманих результатів та проведення нових досліджень по даній тематиці дозволить розробити удосконалені режими зварювання високоміцних сталей 3 урахуванням структурного стану та умов експлуатації металопрокату.

Ключові слова: лазерне зварювання, низьковуглецева сталь, структура зварного з'єднання, структурні складові, зони зварного з'єднання. 